\title{
Bordetella petrii sp. nov., isolated from an anaerobic bioreactor, and emended description of the genus Bordetella
}

\footnotetext{
1 Institut für Mikrobiologie und Hygiene, Universitätsklinikum Charité, Humboldt Universität zu Berlin, Dorotheenstr. 96, D-10117 Berlin, Germany

2 Lehrstuhl für Mikrobiologie, TheodorBoveri-Institut, Universität Würzburg, Am Hubland, D-97074 Würzburg, Germany

3 Institut für Biologie, Humboldt Universität zu Berlin, Chausseestr. 117, D-10115 Berlin, Germany

4 Hahn Meitner Institut Berlin $\mathrm{GmbH}$, Abteilung NG, Glienicker Str. 100, D-14109 Berlin, Germany
}

\author{
Friedrich von Wintzingerode, ${ }^{1}$ Antje Schattke, ${ }^{2}$ Roman A. Siddiqui, ${ }^{3}$ \\ Ullrich Rösick, ${ }^{4}$ Ulf B. Göbel ${ }^{1}$ and Roy Gross ${ }^{2}$
}

Author for correspondence: Ulf B. Göbel. Tel: +49 30 20934715. Fax: +49 3020934703. e-mail: ulf.goebel@charite.de
A novel Bordetella species was isolated from an anaerobic, dechlorinating bioreactor culture enriched from river sediment. The only strain, Se-1111R ${ }^{\top}$ (= DSM $12804^{\top}=$ CCUG $^{43448}{ }^{\top}$ ), for which the name Bordetella petrii is proposed, is designated the type strain of the novel species. Strain Se-1111R was isolated from the dechlorinating mixed culture due to its ability to anaerobically reduce selenate to elemental selenium. Comparative 16S rDNA sequence analysis showed a close relationship between Se-1111 $\mathrm{R}^{\mathrm{T}}$ and members of the genus Bordetella within the $\beta$-Proteobacteria. This close phylogenetic relatedness was also reflected in several metabolic properties of Se-1111R', including its incapacity to utilize carbohydrates, by the high G+C content ( $63.8 \mathrm{~mol} \%)$ of its DNA and by the presence of Q-8 as the major isoprenoid quinone. DNA-DNA hybridization experiments with type strains of all species of the genus Bordetella and closely related species Achromobacter xylosoxidans subsp. denitrificans provided further evidence for the assignment of strain Se-1111R as a novel species of the genus Bordetella. This genus currently consists of seven aerobic species, all of which are known to occur in close pathogenic, opportunistic or possibly commensal relationships with various host organisms. B. petrii is the first member of this genus isolated from the environment and capable of anaerobic growth. The proposal of the novel species and an emended description of the genus Bordetella is presented.

Keywords: Alcaligenaceae, Bordetella, DNA-DNA relatedness, anaerobic selenate reduction, TCB-dechlorinating bioreactor

\section{INTRODUCTION}

The family Alcaligenaceae within the $\beta$-Proteobacteria (Woese et al., 1984, 1985) comprises the genera Bordetella and Alcaligenes. Based on phenotypic and genotypic data, this family also includes the genus Achromobacter (Yabuuchi et al., 1998). However, until now it has not been formally assigned to the family Alcaligenaceae and consequently the term Alcaligenes-Achromobacter-Bordetella complex will

Abbreviation: FBR, fluidized bed reactor.

The GenBank/EMBL accession numbers for the sequences of strain Se$1111 \mathrm{R}^{\top}$ homologous to the ompA and risA genes of $B$. avium are AJ242599 and AJ242553, respectively. be used throughout the text. Bordetella species occur exclusively in close association with humans and various warm-blooded animals, whereas Achromobacter and Alcaligenes species are either environmental or facultative pathogenic organisms (Pittman, 1984; De Ley et al., 1986; Mandell et al., 1987; Busse \& Auling, 1992; Yabuuchi et al., 1998).

Currently, the genus Bordetella comprises seven species. Bordetella pertussis and Bordetella parapertussis are aetiological agents of whooping cough (Hewlett, 1995; Matthews \& Preston, 1997). Whereas $B$. pertussis is an obligate pathogen for humans, $B$. parapertussis strains are also found in sheep where they can cause chronic pneumonia. Human B. parapertussis isolates are highly clonal and appear to be distinct 
from the sheep isolates (Yuk et al., 1998). Bordetella bronchiseptica causes respiratory disease in various mammalian species including dogs, rodents, horses and pigs but only rarely in humans (Woolfrey \& Moody, 1991; Gueirard et al., 1994). Recent data obtained by different molecular genetic techniques, including DNA sequence analysis of virulence genes, comparative 16S rDNA analysis, multilocus enzyme electrophoresis and IS typing, demonstrated that $B$. pertussis, B. parapertussis and B. bronchiseptica were very closely related (Musser et al., 1986; Arico et al., 1987; Müller \& Hildebrandt, 1993; van der Zee et al., 1996, 1997). These data were in agreement with previous DNA-DNA hybridization studies and showed that this group should rather be considered to be subspecies or strains of a single species with different host adaptations than presenting different species (Kloos et al., 1981; Weyant et al., 1995).

Bordetella avium is a pathogen for birds causing severe problems in poultry, especially in turkeys, causing coryza or rhinotracheitis (Arp \& Cheville, 1984; Gentry-Weeks et al., 1992; Temple et al., 1998). Similar to the species belonging to the $B$. bronchiseptica complex, B. avium exhibits a strong tropism for the ciliated epithelium of the upper respiratory tract (Arp $\&$ Cheville, 1984). Physiological and genetic evidence strongly supports the classification of $B$. avium as a distinct species (De Ley et al., 1986; Weiss, 1992; Matthews \& Preston, 1997). Recently, three new species were included in the genus Bordetella, Bordetella hinzii, Bordetella holmesii and Bordetella trematum (Vandamme et al., 1995, 1996; Weyant et al., 1995). B. hinzii is mainly found as a commensal of the respiratory tracts of fowl. It has also some pathogenic potential in immunocompromised humans (Cookson et al., 1994; Vandamme et al., 1995; Funke et al., 1996). Only recently, B. hinzii was reported as the causative agent of fatal septicaemia (Kattar et al., 2000). B. holmesii isolates, previously classified into the so-called CDC non-oxidizer group 2 (NO-2), were included into the genus Bordetella on the basis of genetic and chemotaxonomic analyses (Weyant et al., 1995). It has been isolated repeatedly from blood of young adults and occasionally from sputum (Weyant et al., 1995; Tang et al., 1998). The most recently described member of the genus is $B$. trematum, which was isolated from ear infections and wounds of humans, but never from the respiratory tract. Little is known about the biology of this organism and its pathogenic significance (Vandamme et al., 1996).

Most members of the genus Alcaligenes and Achromobacter are found in the environment. Some of them, e.g. Alcaligenes faecalis and Achromobacter xylosoxidans, are facultative pathogens. In contrast, the bordetellae are generally considered to occur exclusively in close association with various host organisms. Accordingly, the obligate human pathogen B.pertussis is extremely fastidious and sensitive to environmental conditions. Other Bordetella species are more resistant against detrimental growth conditions. For example, it has been shown that $B$. bronchiseptica is able to survive for a prolonged period in buffered saline or lake water without the addition of nutrients (Porter et al., 1991). However, as yet nothing is known about the occurrence of Bordetella species in the environment. The adaptation to a specific host organism may have caused the loss of genetic information resulting in the reduction of some metabolic properties of these species required for survival in the environment. In fact, recent genomic sequencing projects at the Sanger Centre, UK, indicate that the genome size of $B$. pertussis is significantly smaller than that of B. bronchiseptica. In accordance, it has been shown recently that among the factors lost by $B$. pertussis there are genes mainly involved in metabolic functions including biosynthesis of lipopolysaccharide, amino acid metabolism and degradation of aromatic compounds (Middendorf \& Gross, 1999).

In this paper, a novel Bordetella strain, isolated from a mixed anaerobic, dechlorinating culture, which is able to reduce selenate to elemental selenium is described. Comparative 16S rDNA sequence analysis, DNA base composition, isoprenoid quinone content, DNADNA hybridization experiments and several metabolic properties suggest that this organism should be classified within the Alcaligenes-Achromobacter-Bordetella complex and assigned to the genus Bordetella as a novel species, for which the name Bordetella petrii is proposed. To our knowledge, Bordetella petrii is the first member of this genus isolated from the environment and capable of anaerobic growth.

\section{METHODS}

Reference strains. All bacterial strains used in this study are listed in Table 1. B. pertussis, B. parapertussis, B. bronchiseptica and $B$. avium strains were either grown on BG agar plates (Difco) or in SS liquid medium (Stainer \& Scholte, 1970; Gentry-Weeks et al., 1992).

Material, media and culture conditions. Samples were taken from a fluidized bed reactor (FBR) inoculated with an anaerobic, trichlorobenzene-dechlorinating consortium enriched from sediment of the River Saale near Jena, Germany (Selent, 1999). Within the FBR, the dechlorinating consortium was immobilized on polyurethane foam cubes. The microbial diversity of this dechlorinating consortium was investigated by both PCR-amplified $16 \mathrm{~S}$ rDNA clone libraries and 16S rDNA sequence analysis of previously obtained cellular isolates (von Wintzingerode et al., 1999; von Wintzingerode, 1999). For enrichment of anaerobic, selenate-reducing bacteria, foam cubes were removed from the bioreactor using a sterile tweezer and transferred to reduced RAMM medium (Shelton \& Tiedje, 1984). After $7 \mathrm{~d}$ incubation at $30{ }^{\circ} \mathrm{C}$ under anaerobic conditions (GasPak anaerobic jars; Anaerogen), enrichment cultures were set up by transferring one foam cube to each Erlenmeyer flask containing $50 \mathrm{ml}$ Se-medium (Macy et al., 1989) which contained $\left(1^{-1}\right): 2 \cdot 2 \mathrm{~g} \mathrm{NaCl}, 0.3 \mathrm{~g} \mathrm{KCl}, 0.3 \mathrm{~g} \mathrm{NH}_{4} \mathrm{Cl}, 0.2 \mathrm{~g}$ $\mathrm{KH}_{2} \mathrm{PO}_{4}, 0.15 \mathrm{~g} \mathrm{CaCl} .2 \mathrm{H}_{2} \mathrm{O}, 0.4 \mathrm{~g} \mathrm{MgCl}_{2} .6 \mathrm{H}_{2} \mathrm{O}, 0.6 \mathrm{~g}$ $\mathrm{NaHCO}_{3}, 3.78 \mathrm{~g} \mathrm{Na}_{2} \mathrm{SeO}_{4}, 3.78 \mathrm{~g}$ potassium acetate, $10 \mathrm{ml}$ trace metal solution SL8, $10 \mathrm{ml}$ vitamin solution and $800 \mu \mathrm{l}$ methanol. After $5 \mathrm{~d}$ anaerobic incubation in anaerobic jars (Mart, $\mathrm{CO}_{2}, \mathrm{~N}_{2}, \mathrm{H}_{2}$ atmosphere), a red precipitate was 
Table 1. Reference bacterial strains used in this study, and DNA-DNA reassociation rates among strain Se-1111 $\mathrm{R}^{\mathrm{T}}$ and closely related species

\begin{tabular}{|c|c|c|}
\hline Species & Strain/other designation & $\begin{array}{l}\text { Reassociation rate } \\
(\%) \text { with Se-1111R }\end{array}$ \\
\hline Bordetella avium & DSM $11332^{\mathrm{T}} / \mathrm{ATCC} 35086^{\mathrm{T}}$ & $26 \cdot 4$ \\
\hline Bordetella bronchiseptica & CCUG $219^{\mathrm{T}} / \mathrm{ATCC} 19395^{\mathrm{T}}$ & $22 \cdot 9$ \\
\hline Bordetella bronchiseptica & DSM 10303/ATCC 4617 & $22 \cdot 5$ \\
\hline Bordetella bronchiseptica & CCUG 7865/BB7865 & - \\
\hline Bordetella hinzii & DSM $11333^{\mathrm{T}} / \mathrm{LMG} 13501^{\mathrm{T}}$ & $33 \cdot 4$ \\
\hline Bordetella holmesii & CCUG $34073^{\mathrm{T}} /$ ATCC $51541^{\mathrm{T}}$ & $18 \cdot 5$ \\
\hline Bordetella parapertussis & CCUG $413^{\mathrm{T}} / \mathrm{ATCC} 15311^{\mathrm{T}}$ & $35 \cdot 1$ \\
\hline Bordetella parapertussis & DSM $4922 /-$ & - \\
\hline Bordetella pertussis & DSM $5571^{\mathrm{T}} / \mathrm{ATCC} 9797^{\mathrm{T}}$ & $35 \cdot 1$ \\
\hline Bordetella pertussis & Tohama I/ - & - \\
\hline Bordetella trematum & DSM $11334^{\mathrm{T}} /$ CCUG $32381^{\mathrm{T}}$ & $32 \cdot 0$ \\
\hline $\begin{array}{l}\text { Achromobacter xylosoxidans } \\
\text { subsp. denitrificans }\end{array}$ & DSM $30026^{\mathrm{T}} / \mathrm{ATCC} 15173^{\mathrm{T}}$ & $30 \cdot 0$ \\
\hline
\end{tabular}

visible, which served as an inoculum for subcultures in modified Se-medium (Se-medium with $1.2 \mathrm{~g} \mathrm{NaCl}^{-1}$ and additional $1-4 \mathrm{~g}$ yeast extract $\mathrm{l}^{-1}, 0 \cdot 3 \mathrm{~g} \mathrm{Na}_{2} \mathrm{SO}_{4} \mathrm{l}^{-1}$ and $2 \cdot 02 \mathrm{~g}$ $\left.\mathrm{KNO}_{3} 1^{-1}\right)$. A pure culture was achieved by repeated streaking on agar plates containing the above-mentioned medium (1.5\% agar, anaerobic incubation). Cells were stored at $-70{ }^{\circ} \mathrm{C}$ in liquid growth medium supplemented with $30-50 \%$ (v/v) glycerol.

Determination of anaerobic selenate reduction. Strain Se$1111 \mathrm{R}^{\mathrm{T}}$ was grown anaerobically in cultures containing $10 \mathrm{ml}$ basic medium (Se-medium without methanol, supplemented with $0.02 \mathrm{~g} \mathrm{KNO}_{3} \mathrm{I}^{-1}$ and $4 \mathrm{~g}$ yeast extract $\mathrm{l}^{-1}$ ) at $30{ }^{\circ} \mathrm{C}$ for $30 \mathrm{~d}$. An anaerobic culture grown in basic medium without selenate served as control. An aliquot of the culture $(2.5 \mathrm{ml})$ was withdrawn for determination of whole-cell proteins using the DC protein assay kit (Bio-Rad) as suggested by the manufacturer. For determination of elemental selenium, an aliquot of the remaining culture $(7.0 \mathrm{ml})$ was removed. Cells were collected by centrifugation $(2500 \mathrm{~g}, 60 \mathrm{~min})$ in FEP vials (tetrafluorethylene-perfluorethylene) and washed two times each with $8.5 \mathrm{ml}$ PBS (138 mM NaCl, 2.7 mM KCl, 8.1 mM Na $\mathrm{HPO}_{4}, 1.8 \mathrm{mM}$ $\mathrm{KH}_{2} \mathrm{PO}_{4}, \mathrm{pH} 7 \cdot 4$ ) to remove soluble selenium salts. The resulting cell pellet was lysed in $1.0 \mathrm{ml}$ suprapure nitric acid (Merck) by pressurized digestion $\left(2 \mathrm{~h}\right.$ at $110^{\circ} \mathrm{C}$ and $3 \mathrm{~h}$ at $160^{\circ} \mathrm{C}$ ). Selenium was determined by electrothermal atomic absorption spectrometry using a Perkin-Elmer 5100 spectrometer. To test for reproducibility all experiments were perfomed with four cultures in parallel (both selenatecontaining cultures and controls).

Phenotypic tests. For phenotypic tests, cells of strain Se$1111 \mathrm{R}^{\mathrm{T}}$ were grown aerobically on LB agar at $30^{\circ} \mathrm{C}$ for $48 \mathrm{~h}$. Growth and haemolysis were evaluated on MacConkey III agar plates (Oxoid), Columbia blood agar plates (BectonDickinson) and on BG agar plates containing $15 \%(\mathrm{v} / \mathrm{v})$ defibrinated horse blood (Difco), respectively. Reduction of tetrazolium was determined on LB agar plates supplemented with $75 \mathrm{mg}$ 2,3,5-triphenyltetrazolium chloride (Sigma) $1^{-1}$. Motility was tested by both phase-contrast microscopy of overnight cultures grown in LB liquid media at $30^{\circ} \mathrm{C}$ and by examining colony morphology on LB swarming agar $(0 \cdot 8 \mathrm{~g}$ $\mathrm{NaCl}^{-1}, 0 \cdot 3 \%$, w/v agar). Oxidase and catalase activities were tested with oxidase test strips (Merck) and by mixing cells of a single colony with a $3 \%(\mathrm{v} / \mathrm{v}) \mathrm{H}_{2} \mathrm{O}_{2}$ solution on a microscopic slide, respectively.

The API 20NE, API 50CH, API 20A and API 20E were used as recommended by the manufacturer (bioMérieux). All tests were repeated at least twice.

$16 S$ rDNA sequencing and phylogenetic analyses. The nearly complete $16 \mathrm{~S}$ rRNA genes (1523 bp) of the novel strain Se$1111 \mathrm{R}^{\mathrm{T}}$ and reference strains $B$. trematum DSM $11334^{\mathrm{T}}, B$. bronchiseptica DSM 10303, B. parapertussis DSM 4922 and Achromobacter xylosoxidans subsp. denitrificans DSM $30026^{\mathrm{T}}$ were determined. Small subunit rRNA genes were PCR-amplified from cell lysates using primers TPU1 (5'AGAGTTTGATCMTGGCTCAG-3'; Escherichia coli positions 8-27) and RTU8 (5'-AAGGAGGTGATCCANCCRCA-3'; E. coli positions 1522-1541) (modified from Weisburg et al., 1991) and were subsequently cloned into the pCR2.1 vector by TOPO TA cloning (Invitrogen). 16S rDNA inserts were sequenced using IR dye-labelled vectorspecific M13 primers and 16S rDNA-specific primers and the ThermoSequenase Fluorescent Labelled Primer Cycle Sequencing kit (Amersham-Pharmacia). Sequencing reactions were analysed on an automated LICOR DNA4000L sequencer (MWG-BIOTECH). Sequence alignment and phylogenetic analyses were performed by using the ARB software package (Ludwig \& Strunk, 1997). A total of 1313 bases was used for phylogenetic analyses by using the shortest $16 \mathrm{~S}$ rRNA sequence of the alignment as a filter (Achromobacter ruhlandii, EMBL accession no. AB010841). Uncertain sequence positions were excluded from phylogenetic analyses. Evolutionary trees were constructed by applying distance matrix (ARB, neighbour-joining with the correction of Jukes \& Cantor, 1969), parsimony (ARB, PHYLIP, DNAPARS; Felsenstein, 1993) and compatibility criterion methods (ARB, PHYLIP, DNACOMP; Felsenstein, 1993). To provide confidence estimates for tree topologies, 100 bootstrapped replicate resamplings were performed.

DNA base composition, DNA-DNA hybridizations and isoprenoid quinone analysis. DNA was isolated as described by Cashion et al. (1977). The mean $\mathrm{G}+\mathrm{C}$ value of the DNA was determined by HPLC (Mesbah et al., 1989). The degrees of DNA-DNA binding were determined spectrometrically by the initial renaturation rate method (De Ley et al., 1970) with modifications described by $\mathrm{Hu}$ et al. (1983) and Escara 
$\&$ Hutton (1980). The renaturation of the nucleic acids was monitored using a Gilford spectrometer model 2600 equipped with a temperature programmer (Gilford model $2527-\mathrm{R})$. The renaturation ratios were calculated using the program TRANSFER.BAS (Jahnke, 1992). Isoprenoid quinones were extracted from $100 \mathrm{mg}$ lyphilized cells and analysed by reverse-phase HPLC (Moss \& Guerrant, 1983). All experiments were performed by the Deutsche Sammlung von Mikroorganismen und Zellkulturen GmbH (DSMZ, Braunschweig, Germany).

Southern blotting. Chromosomal DNA was prepared as described by Stibitz \& Garletts (1992). The bacteria were grown in the appropriate medium at $37{ }^{\circ} \mathrm{C}$ to the exponential growth phase, harvested by centrifugation and resuspended in $10 \mathrm{mM}$ Tris $/ \mathrm{HCl} / 20 \mathrm{mM} \mathrm{NaCl}, \mathrm{pH} 7 \cdot 2$ to give a final concentration of $2 \times 10^{9}$ cells $\mathrm{ml}^{-1}$. The suspension was mixed with an equal volume of $2 \%(\mathrm{w} / \mathrm{v})$ low-melting-point agarose prepared in the same buffer, pipetted into casting moulds and allowed to cool. Solidified plugs were incubated in lysozyme buffer [ $10 \mathrm{mM}$ Tris $/ \mathrm{HCl} / 50 \mathrm{mM} \mathrm{NaCl} / 0 \cdot 2 \%$ sodium deoxycholate $/ 0.5 \%$ sodium $N$-laurylsarcosine/ $1 \mathrm{mg}$ lysozyme (Merck) $\mathrm{ml}^{-1}, \mathrm{pH} 7 \cdot 2$ ) with gentle agitation at $37^{\circ} \mathrm{C}$ for $2 \mathrm{~h}$. After washing at room temperature in $20 \mathrm{mM}$ Tris $/ \mathrm{HCl} / 50 \mathrm{mM}$ EDTA, $\mathrm{pH} 7 \cdot 2$, plugs were treated with proteinase $\mathrm{K}$ buffer $[100 \mathrm{mM}$ EDTA/1\% sodium $N$ laurylsarcosine $/ 0 \cdot 2 \%$ sodium deoxycholate $/ 2 \mathrm{mg}$ proteinase $\mathrm{K}$ (Merck) $\mathrm{ml}^{-1}$ ] at $50{ }^{\circ} \mathrm{C}$ overnight. Proteinase $\mathrm{K}$ was removed by washing at room temperature in $20 \mathrm{mM}$ Tris $/ \mathrm{HCl} / 50 \mathrm{mM}$ EDTA, pH $7 \cdot 2$ for at least $1 \mathrm{~h}$. Samples were then equilibrated in TE buffer $(10 \mathrm{mM}$ Tris $/ \mathrm{HCl} / 1 \mathrm{mM}$ EDTA, $\mathrm{pH} 8.0$ ) and stored at $4{ }^{\circ} \mathrm{C}$. For restriction enzyme digestion, slices of the plugs were incubated in $200 \mu \mathrm{l}$ respective buffer at $50{ }^{\circ} \mathrm{C}$ for $1 \mathrm{~h}$. Enzyme was then added and slices were incubated at $37^{\circ} \mathrm{C}$ overnight. Reactions were stopped by addition of $20 \mu \mathrm{l} 45 \%$ saccharose/100 mM EDTA containing $0 \cdot 1 \%$ bromophenol blue. Plugs were then chilled on ice prior to loading onto a $1 \%$ agarose gel. Gels were run at $200 \mathrm{~V}$ in $0.5 \times$ TBE buffer $(1 \times$ is $89 \mathrm{mM}$ Tris$\mathrm{HCl}, 89 \mathrm{mM}$ borate, $0.2 \mathrm{mM}$ EDTA, $\mathrm{pH} 8.0$ ) at $14^{\circ} \mathrm{C}$ in a contour-clamped homogeneous electric field DR III apparatus (Bio-Rad). Pulsed-field gels were blotted on a model 785 vacuum blotter (Bio-Rad) following the manufacturer's instructions. For hybridization, the ECL labelling and signal detection system was used (Amersham-Pharmacia). DNA fragments containing parts of the coding regions for the pertussis toxin, adenylate cyclase toxin, dermonecrotic toxin, filamentous haemagglutinin, pertactin, fimbriae (serotypes 2 and 3), the BvgAS two-component system, the RisA response regulator and the outer-membrane protein A were used as probes for the hybridization experiments (Klein, 1999).

PCR amplification and sequencing of putative coding regions. For PCR amplification of parts of the putative open reading frames of strain Se-1111 $\mathrm{R}^{\mathrm{T}}$ homologous to the omp $A$ and ris $A$ genes of $B$. avium, the following primers were used which were designed according to the $B$. avium DNA sequences: omple (5'-CCCTCCAAATTCGCTCTGGCGCTT-3'), omp2b (5'-GTCCAGTTCGGCCTGGTCTACGTT-3'), risalc (5'-AAAACACCACTCCTACCCGCAAGA-3') and risa2d (5'-CCCAGGCCCCAGACGGTTTGGATG-3'). PCR products were purified using the QIAquick PCR purification kit (Qiagen) and sequenced using an automatic DNA sequencer model ABIPRISM 377 (PE Applied Biosystems). For comparative sequence analysis, the respective programs of the GCG software package were used (Devereux et al., 1984).

\section{RESULTS AND DISCUSSION}

\section{Cultural and morphological characteristics}

Using culture conditions favouring anaerobic, respiratory selenate reduction, strain $\mathrm{Se}-1111 \mathrm{R}^{\mathrm{T}}$ was isolated from a dechlorinating microbial consortium. It formed small, irregular, slightly red coloured colonies when grown under anaerobic conditions on selenate-containing medium. Phase-contrast microscopy of 48 h LB cultures revealed non-motile, Gramnegative, predominantly short or coccoid rods $(0.6 \mu \mathrm{m}$ in width and $1.5 \mu \mathrm{m}$ in length) with rare longer and wider forms that sometimes occurred as chains. Electron microscopy showed the presence of fimbriae on the cell surface and the occurrence of bacteriophages in the preparation (Fig. 1).

\section{Metabolic properties}

The general metabolic properties of strain Se-1111R are characterized by its ability to grow under aerobic, microaerophilic and anaerobic conditions. With regard to its substrate spectrum, the novel isolate was an asaccharolytic, non-fermenting bacterium. The following characteristics were in common with all other members of the genus Bordetella (Vandamme et al., 1996): aerobic and microaerobic growth at $37^{\circ} \mathrm{C}$; aerobic growth at $30{ }^{\circ} \mathrm{C}$; assimilation of citrate; and catalase activity.

The following characteristics were negative for strain Se-1111R $\mathrm{R}^{\mathrm{T}}$, as well as for all other members of the genus Bordetella (Vandamme et al., 1996): production of acetylmethylcarbinol and indole; gelatin liquefaction; aesculin hydrolysis; and assimilation of $\mathrm{D}$ -

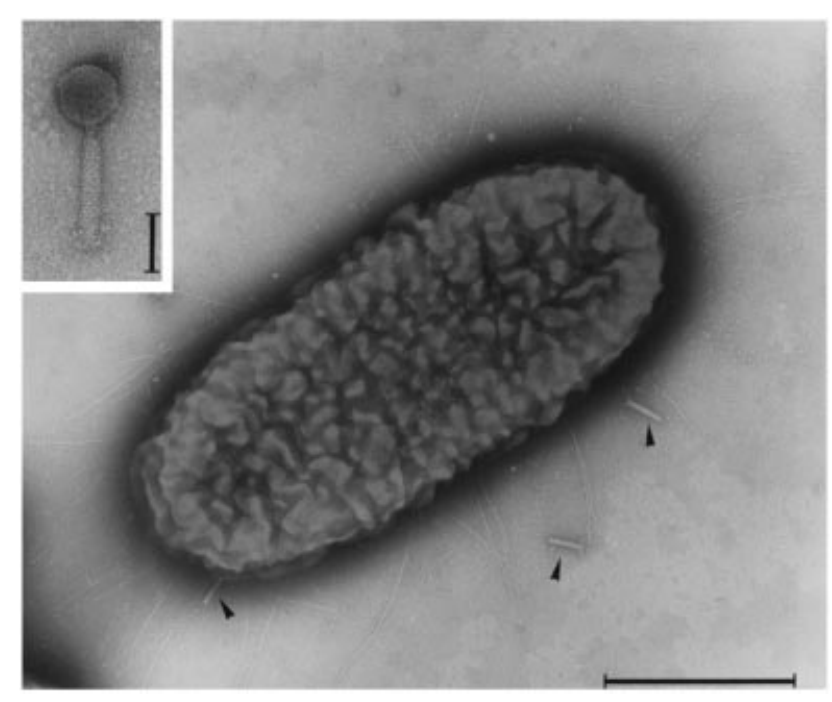

Fig. 1. Transmission electron micrograph (negatively stained) of a single cell of strain Se-1111R . Fimbriae are located on the cell surface. Arrows indicate bacteriophage tails (bar, $0.5 \mu \mathrm{m}$ ). An intact bacteriophage is shown in the inset (bar, 0.05 $\mu \mathrm{m})$ ( $R$. Lurz, MPI für Molekulare Genetik, Berlin, Germany). 
Table 2. Phenotypic characteristics of strain Se-1111 $\mathrm{R}^{\mathrm{T}}$ and closely related species (Vandamme et al., 1996)

Strains: 1, Se-1111R $\mathrm{R}^{\mathrm{T}} ; 2$, B. avium; 3, B. hinzii; 4, B. holmesii; 5, B. trematum; 6, B. pertussis; 7 , B. parapertussis; 8, B. bronchiseptica; 9, Achromobacter xylosoxidans subsp. denitrificans. + , Positive; - , negative; ND, not determined; v, strain-dependent.

\begin{tabular}{|lccccccccc|}
\hline Characteristic & $\mathbf{1}$ & $\mathbf{2}$ & $\mathbf{3}$ & $\mathbf{4}$ & $\mathbf{5}$ & $\mathbf{6}$ & $\mathbf{7}$ & $\mathbf{8}$ & $\mathbf{9}$ \\
\hline Growth on MacConkey agar & + & + & + & - & + & - & + & + & + \\
Motility & - & + & + & - & + & - & - & + & + \\
Fimbriae & + & + & $\mathrm{ND}$ & $\mathrm{ND}$ & $\mathrm{ND}$ & + & + & + & $\mathrm{ND}$ \\
Urease & - & - & - & - & - & - & + & + & - \\
Oxidase & + & + & + & - & - & + & - & + & + \\
Haemolysis & - & - & $\mathrm{ND}$ & $-*$ & $\mathrm{ND}$ & $+\dagger$ & $+\dagger$ & $+\dagger$ & $\mathrm{ND}$ \\
Tetrazolium reduction & + & + & + & + & + & $\mathrm{ND}$ & + & + & + \\
Nitrate reduction (API 20NE) & & & & & & & & & \\
Formation of nitrite & - & - & - & - & $\mathrm{V}$ & - & - & + & + \\
Denitrification & + & - & - & - & $\mathrm{V}$ & - & - & - & -+ \\
Assimilation of: & & & & & & & & & \\
$\quad$ Caprate & - & - & + & - & - & - & - & $\mathrm{V}$ & + \\
$\quad$ D-Gluconate & + & - & - & - & - & - & - & - & - \\
$\quad$ L-Malate & + & + & + & - & + & - & - & $\mathrm{V}$ & + \\
$\quad \begin{array}{l}\text { Adipate } \\
\text { Phenylacetate }\end{array}$ & + & + & + & - & + & - & - & $\mathrm{V}$ & + \\
\hline
\end{tabular}

* Weyant et al. (1995).

$\dagger$ Weiss (1992).

+ Positive with classical method.

glucose, D- and L-arabinose, mannose, mannitol, $\mathrm{N}$ acetylglucosamine, maltose, glycerol, erythritol, ribose, $\mathrm{L}$ - and D-xylose, adonitol, rhamnose, methyl $\beta$ D-xyloside, inositol, sorbitol, methyl $\alpha$-D-glucoside, amygdalin, arbutin, salicin, cellobiose, lactose, melibiose, saccharose, trehalose, inulin, melezitose, raffinose, starch, glycogen, xylitol and gentiobiose. Under anaerobic conditions, no growth occurred with the following substrates: glucose; mannitol; lactose; saccharose; maltose; xylose; salicin; arabinose; glycerol; cellobiose; mannose; melezitose; raffinose; sorbitol; rhamnose; or trehalose. All of the remaining characteristics are shown in Table 2.

\section{Anaerobic selenate reduction}

As judged from the amount of whole-cell protein, strain Se-1111 $\mathrm{R}^{\mathrm{T}}$ grew equally well under anaerobic conditions in medium containing nitrate and selenate and in medium containing only nitrate $(333 \mu \mathrm{g}$ protein $\mathrm{ml}^{-1}$ ). The ratio of elemental selenium formed to whole-cell protein was $200 \mathrm{fg}$ selenium ( $\mu \mathrm{g}$ protein $)^{-1}$.

\section{Phylogenetic classification}

The nearly complete 16S rRNA gene $(1523 \mathrm{bp})$ of strain Se-1111R $\mathrm{R}^{\mathrm{T}}$ was sequenced. Furthermore, the $16 \mathrm{~S}$ rRNA gene sequence of the type strain of $B$. trematum (DSM $11334^{\mathrm{T}}$ ) was determined to include all
Bordetella species in phylogenetic analyses. Fig. 2 shows the phylogenetic relationship of strain Se$1111 \mathrm{R}^{\mathrm{T}}$ within the Alcaligenes-AchromobacterBordetella complex, as determined by comparative $16 \mathrm{~S}$ rRNA gene sequence analyses. With all treeing algorithms, strain Se-1111 $\mathrm{R}^{\mathrm{T}}$ constituted a separate branch and Bordetella spp. were its closest neighbours. Strain Se-1111R $\mathrm{R}^{\mathrm{T}}$ and Bordetella spp. were clearly separated from a cluster comprising all validly described Achromobacter spp., as well as several strains isolated from a soil microarthropod (strains R5, R6 and 151; Hoffmann et al., 1998), the rhizosphere of rapeseed (strain 3-17; Bertrand et al., 1996) and trichloroethylene-degrading soil isolate KP22 (Hanada et al., 1998). Within the Bordetella cluster and the Achromobacter cluster, branching orders differed among the various algorithms. Despite variations in cluster-specific branching patterns and low bootstrap values, overall tree topologies were in agreement with recent studies, which showed that Bordetella spp. and members of the genus Achromobacter formed two closely related $16 \mathrm{~S}$ rRNA clusters, clearly separated from Alcaligenes spp. (Yabuuchi et al., 1998; Kattar et al., 2000). It is therefore concluded that strain Se- $1111 \mathrm{R}^{\mathrm{T}}$ is phylogenetically affiliated to the genus Bordetella. Sequence similarities between strain Se-1111 $\mathrm{R}^{\mathrm{T}}$ and members of the genus Bordetella were $97.9-98.6 \%$ with the highest value to $B$. bronchiseptica and $B$. parapertussis. In contrast, sequence similarities to members of the genus Achromobacter 


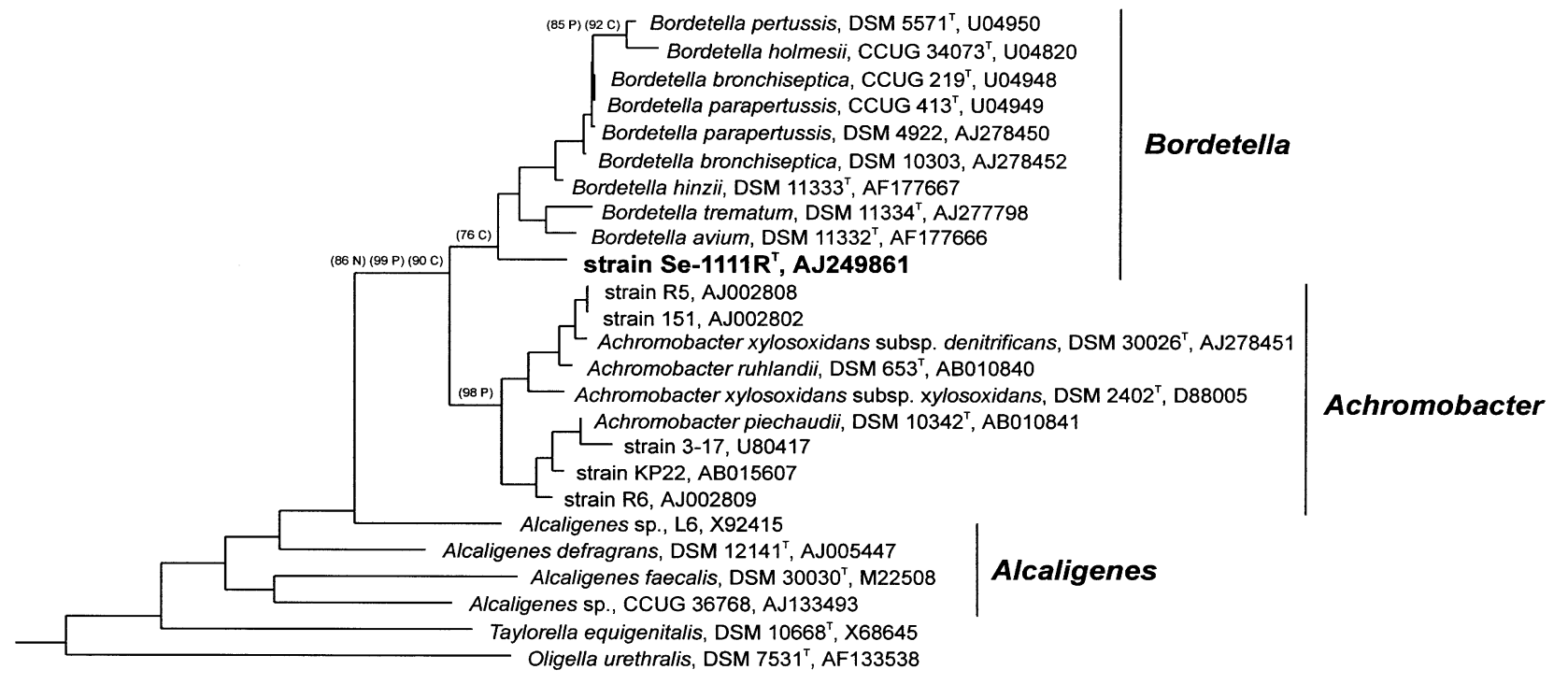

$10 \%$

Fig. 2. Phylogenetic tree based on 1313 consecutive positions of the $16 \mathrm{~S}$ rRNA gene of strain Se-1111 $\mathrm{R}^{\top}$ and members of the genera Bordetella, Achromobacter and Alcaligenes within the $\beta$-Proteobacteria. The dendrogram was generated using the neighbour-joining method with 100 bootstrap resamplings. Phylogenetic trees generated by the parsimony and the compatibility criterion methods showed identical overall tree topologies. Branching patterns within the Bordetella and the Achromobacter clusters changed among different algorithms. Numbers at branching points indicate bootstrap proportions of confidence in percentages ( $N$, neighbour-joining; $\mathrm{P}$, parsimony; $\mathrm{C}$, compatibility). Only values $\geqslant 70 \%$ are shown. Zoogloea ramigera ATCC $19544^{\top}$ (EMBL accession no. D14254) was used as an outgroup. Bar, $10 \%$ estimated sequence divergence.

were lower $(97 \cdot 4-97.9 \%)$ with the highest value to Achromobacter xylosoxidans subsp. xylosoxidans.

\section{DNA base composition and isoprenoid quinone analysis}

The DNA $\mathrm{G}+\mathrm{C}$ content of strain Se-1111R $\mathrm{R}^{\mathrm{T}}$ was $63 \cdot 8 \pm 0.5 \mathrm{~mol} \%$. The only isoprenoid quinone detectable was Q-8.

\section{DNA-DNA hybridizations}

DNA-DNA hybridization rates determined with the type strains of all Bordetella spp. and Achromobacter xylosoxidans subsp. denitrificans were all below the threshold value of $70 \%$ (Wayne et al., 1987) indicating that strain Se-1111 $\mathrm{R}^{\mathrm{T}}$ represents a distinct species (Table 1).

\section{Identification of open reading frames highly similar to genes encoded by various Bordetella spp.}

To investigate the presence of well-characterized genes of various Bordetella species, hybridization experiments were performed with DNA fragments containing parts of the genes encoding pertussis toxin, filamentous haemagglutinin, fimbriae (serotypes 2 and
3), pertactin, dermonecrotic toxin, adenylate cyclase toxin, the BvgAS two-component system, the RisA response regulator and the OmpA outer-membrane protein. Positive results were obtained for all corresponding control organisms (e.g. B. pertussis and pertussis toxin gene probe). However, with strain Se$1111 \mathrm{R}^{\mathrm{T}}$ strong and reproducible hybridization signals could be detected only for the omp $A$ and ris $A$ genes (Fig. 3). To evaluate the degree of similarity of these DNA fragments to their Bordetella counterparts, parts of the coding regions of the putative omp $A$ and ris $A$ genes were PCR-amplified using primers derived from the respective DNA sequences of B. avium. In both cases, PCR fragments of the expected length (461 and $445 \mathrm{bp}$, respectively) were obtained. While the ris $A$ genes of $B$. pertussis, $B$. parapertussis, $B$. bronchiseptica and B. avium are identical (Jungnitz et al., 1998), the ris $A$-like gene of strain Se- $1111 \mathrm{R}^{\mathrm{T}}$ contained several point mutations corresponding to a sequence divergence of $10.5 \%$. However, all mutations found were conservative, encoding identical amino acid sequences. In the case of the omp $A$ gene, strain $\mathrm{Se}-1111 \mathrm{R}^{\mathrm{T}}$ exhibited $14.0 \%$ divergence to a consensus sequence derived from the aligned DNA sequences of Se$1111 \mathrm{R}^{\mathrm{T}}$, B. avium, B. bronchiseptica, and B. pertussis. In contrast, B. avium, B. bronchiseptica and B. pertussis showed $9 \cdot 1,7 \cdot 1$ and $6 \cdot 3 \%$ divergence, respectively. 


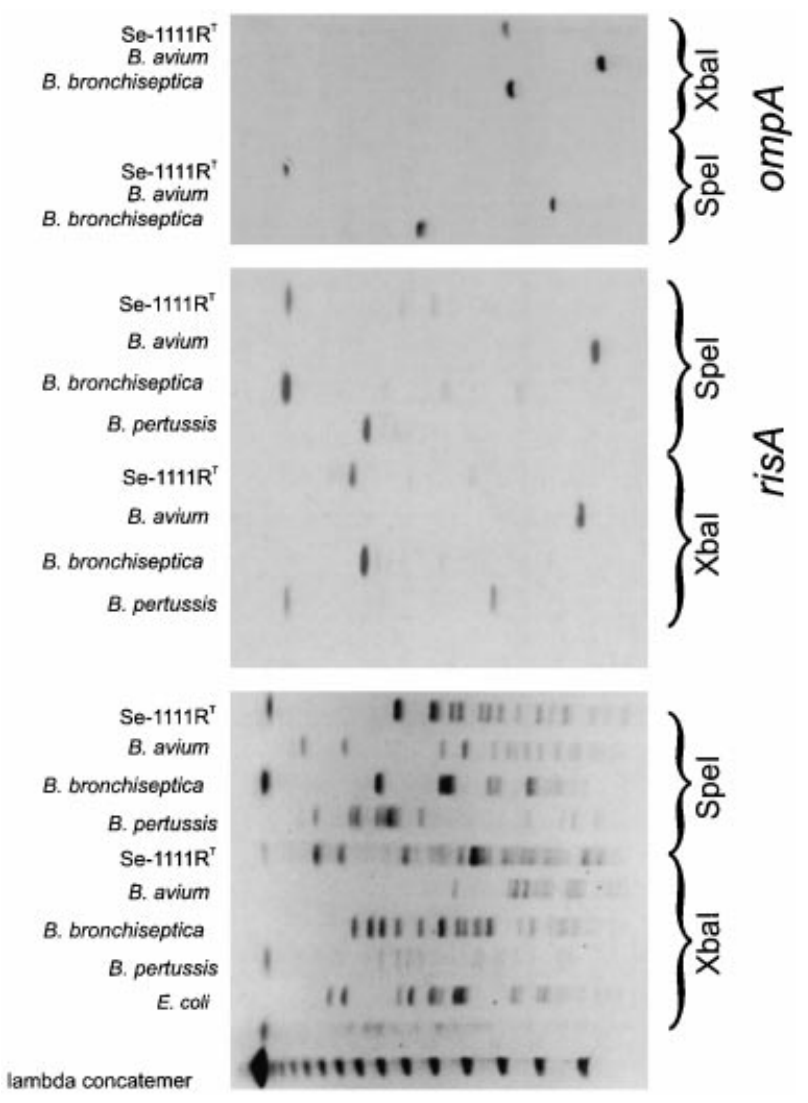

Fig. 3. Southern blots of $X b a l-$ and Spel-digested chromosomal DNA demonstrating the genomic distribution of the ris $A$ and ompA genes in various Bordetella strains and strain Se-1111 $\mathrm{R}^{\mathrm{T}}$.

\section{Taxonomic position of strain Se-1111R}

Both biochemical and chemotaxonomic characteristics showed that strain $\mathrm{Se}-1111 \mathrm{R}^{\mathrm{T}}$ is a member of the Alcaligenes-Achromobacter-Bordetellacomplex. Comparative $16 \mathrm{~S}$ rRNA gene sequence analyses affiliated strain Se-1111R ${ }^{\mathrm{T}}$ with Bordetella spp. and clearly separated it from closely related Achromobacter spp. Despite phenotypic differences between strain Se$1111 \mathrm{R}^{\mathrm{T}}$ and Bordetella spp. (anaerobic growth, aerobic utilization of D-gluconate), it is concluded that strain Se-1111R $\mathrm{R}^{\mathrm{T}}$ does not represent a novel genus but is a member of the genus Bordetella. DNA-DNA hybridization values obtained with the type strains of all Bordetella spp. revealed that strain Se-1111R ${ }^{\mathrm{T}}$ represents a novel species within this genus, proposed as $B$. petrii.

To our knowledge, B. petrii is the first species of this genus isolated from the environment and capable of anaerobic growth. As judged from Southern blot hybridization, $B$. petrii does not appear to have the BvgAS signal transduction system, which regulates the infectious cycle of Bordetella species, or any of the virulence-related genes tested for. However, as all other Bordetella species and many Alcaligenes and Achromobacter species are pathogenic or facultative pathogenic organisms, the pathogenic potential of $B$. petrii in several infection models is in the process of being analysed.

\section{Description of Bordetella petrii sp. nov.}

Bordetella petrii [pe'trii. N.L. gen. n. petrii of Petri, named in honour of R. J. Petri, an early German microbiologist who developed the Petri-dish (Petri, 1887)].

$B$. petrii was isolated from an anaerobic, dechlorinating mixed culture which had been enriched from river sediment (Saale near Jena, Germany). Its pathogenic significance remains unknown. Cells are Gramnegative, non-spore-forming, non-motile and rodshaped to circular. Cells are $0.4-0.7 \mu \mathrm{m}$ wide to $1.0-2.8 \mu \mathrm{m}$ in length. Cells possess fimbriae of different diameters. Colonies are of white-creamy colour and differ in size. Growth occurs under both aerobic and anaerobic conditions. Anaerobic growth is non-fermentative, possibly due to denitrification or to selenate reduction to elemental selenium. Some biochemical characteristics are described in the text and in Table 2. The major respiratory isoprenoid quinone is Q-8. The $\mathrm{G}+\mathrm{C}$ content is $63.8 \mathrm{~mol} \%$. Strain $\mathrm{Se}-1111 \mathrm{R}^{\mathrm{T}}$ is designated the type strain $\left(=\mathrm{DSM} 12804^{\mathrm{T}}=\mathrm{CCUG}\right.$ $\left.43448^{\mathrm{T}}\right)$.

\section{Emendation of description of the genus Bordetella (Skerman et al. 1980)}

Based on the study of phenotypic and chemotaxonomic characteristics and comparative 16S rRNA gene sequence analysis of strain Se-1111R $\mathrm{R}^{\mathrm{T}}$, the type strain of the species Bordetella petrii, the following emended description of the genus Bordetella is proposed.

Gram-negative, catalase-positive, asaccharolytic coccobacilli with an DNA G + C content of 60-69 mol \%. Growth occurs strictly aerobically, facultatively anaerobically and non-fermentatively. One species is able to grow anaerobically under conditions favouring respiratory nitrate and selenate reduction. Species assimilate citrate under aerobic conditions, one species assimilates D-gluconate. Additional biochemical attributes are given in Results. The major respiratory isoprenoid quinone is Q-8. Strains were isolated from humans and warm-blooded animals, one strain was isolated from the environment. Based on comparative 16S rRNA gene sequence analysis, the species forms a distinct cluster separated from members of the genera Achromobacter and Alcaligenes within the $\beta$-Proteobacteria. The type species of the genus is Bordetella pertussis.

\section{ACKNOWLEDGEMENTS}

The authors would like to thank Rudi Lurz (MPI für Molekulare Genetik, Berlin) for EM-micrographs, Burkhard Selent (TU-Berlin) for running the bioreactor, Klaus Heuner and Cord Schlötelburg for helpful comments, 
and Ursula Stegert and Ursula Dziuba for technical assistance. The work was supported by grants from the Deutsche Forschungsgemeinschaft (SFB479/A2 to R.G. and Sfb193/D6-YE1 and SCHN 317/6-5 to U.B.G.), by the Fonds der Chemischen Industrie (R. G.) and by the Studienstiftung des Deutschen Volkes (F.v.W.).

\section{REFERENCES}

Arico, B., Gross, R., Smida, J. \& Rappuoli, R. (1987). Evolutionary relationships in the genus Bordetella. Mol Microbiol 1, 301-308.

Arp, L. H. \& Cheville, N. F. (1984). Tracheal lesions in young turkeys infected with Bordetella avium. Am J Vet Res 45 , 2196-2200.

Bertrand, H., Normand, P. \& Cleyet-Marel, J.-C. (1996). EMBL accession no. U80417.

Busse, H. J. \& Auling, G. (1992). The genera Alcaligenes and 'Achromobacter'. In The Prokaryotes, 2nd edn, pp. 2544-2555. Edited by A. Balows, H. G. Trüper, M. Dworkin, W. Harder \& K.-H. Schleifer. New York: Springer.

Cashion, P., Hodler-Franklin, M. A., McCully, J. \& Franklin, M. (1977). A rapid method for base ratio determination of bacterial DNA. Anal Biochem 81, 461-466.

Cookson, B. T., Vandamme, P., Carlson, L. C., Larson, A. M., Sheffield, J. V. L., Kersters, K. \& Spach, D. H. (1994). Bacteremia caused by a novel Bordetella species, 'B. hinzii'. J Clin Microbiol 32, 2569-2571.

De Ley, J. P., Cattoir, H. \& Reynaerts, A. (1970). The quantitative measurement of DNA hybridization from renaturation rates. Eur J Biochem 12, 133-142.

De Ley, J., Segers, P., Kersters, K., Mannheim, W. \& Lievens, A. (1986). Intra- and intergeneric similarities of the Bordetella ribosomal ribonucleic acid cistrons: proposal for a new family, Alcaligenaceae. Int J Syst Bacteriol 36, 405-414.

Devereux, J., Haeberli, P. \& Smithies, O. (1984). A comprehensive set of sequence analysis programs for the VAX. Nucleic Acids Res 12, 387-395.

Escara, J. F. \& Hutton, J. R. (1980). Thermal stability and renaturation of DNA in dimethylsulphoxide solutions: acceleration of renaturation rate. Biopolymers 19, 1315-1327.

Felsenstein, J. (1993). PHYLIP (Phylogeny Inference Package) version 3.5. Department of Genetics, University of Washington, Seattle, WA, USA.

Funke, G., Hess, T., von Graevenitz, A. \& Vandamme, P. (1996). Characteristics of Bordetella hinzii strains isolated from a cystic fibrosis patient over a 3-year period. J Clin Microbiol 34, 966-969.

Gentry-Weeks, C. R., Hultsch, A. L., Kelly, S. M., Keith, J. M. \& Curtiss, R., III (1992). Cloning and sequencing of a gene encoding a 21-kilodalton outer membrane protein from Bordetella avium and expression of the gene in Salmonella typhimurium. $J$ Bacteriol 174, 7729-7742.

Gueirard, P., Weber, C., LeCoustumier, A. \& Guiso, N. (1994). Human Bordetella bronchiseptica infection related to contact with infected animals: persistence of bacteria in host. $J$ Clin Microbiol 33, 2002-2006.

Hanada, S., Shigematsu, T., Shibuya, K., Eguchi, M., Hasegawa, T., Suda, F., Kamagata, Y., Kanagawa, T. \& Kurane, R. (1998). Phylogenetic analysis of trichloroethylene-degrading bacteria newly isolated from soil polluted with this contaminant. $J$ Ferment Bioeng 86, 539-544.

Hewlett, E. L. (1995). Bordetella species. In Principles and
Practice of Infectious Diseases, pp. 2078-2084. Edited by G. L. Mandell, R. G. Douglas \& J. E. Bennett. New York: Churchill Livingstone.

Hoffmann, A., Thimm, T., Dröge, M., Moore, E. R. B., Munch, J. C. \& Tebbe, C. C. (1998). Intergeneric transfer of conjugative and mobilizable plasmids harbored by Escherichia coli in the gut of the soil microarthropod Folsomia candida (Collembola). Appl Environ Microbiol 64, 2652-2659.

Huß, V. A. R., Festl, H. \& Schleifer, K.-H. (1983). Studies on the spectrometric determination of DNA hybridization from renaturation rates. J Syst Appl Microbiol 4, 184-192.

Jahnke, K.-D. (1992). Basic computer program for evaluation of spectroscopic DNA renaturation data from GILFORD System 2600 spectrometer on a PC/XT/AT type personal computer. $J$ Microbiol Methods 15, 61-73.

Jukes, T. H. \& Cantor, C. R. (1969). Evolution of protein molecules. In Mammalian Protein Metabolism, vol. 3, pp. 21-132. Edited by H. N. Munro. New York: Academic Press.

Jungnitz, H., West, N.P., Walker, M. J., Chhatwal, G. S. \& Guzman, C. A. (1998). A second two-component regulatory system of Bordetella bronchiseptica required for bacterial resistance to oxidative stress, production of acid phosphatase, and in vivo persistence. Infect Immun 66, 4640-4650.

Kattar, M. M., Chavez, A. P., Limaye, A. P. \& 7 other authors (2000). Application of $16 \mathrm{~S}$ rRNA gene sequencing to identify Bordetella hinzii as the causative agent of fatal septicemia. J Clin Microbiol 38, 789-794.

Klein, A. (1999). Vergleichende genetische Charakterisierung verschiedener Bordetella-Isolate. Diploma thesis: Universität Würzburg.

Kloos, W. E., Mohapatra, N., Dobrogosz, W. J., Ezzell, J. W. \& Manclark, C. R. (1981). Deoxyribonucleotide sequence relationships among Bordetella species. Int J Syst Bacteriol 31, 173-176.

Ludwig, W. \& Strunk, O. (1997). ARB : a software environment for sequence data, version 2.5b. http://www.mikro.biologie.tumuenchen.de/pub/ARB/documentation/ARB.ps.

Macy, J. M., Michel, T. A. \& Kirsch, D. G. (1989). Selenate reduction by a Pseudomonas species: a new mode of anaerobic respiration. FEMS Microbiol Lett 61, 195-198.

Mandell, W. F., Garvey, G. J. \& Neu, H. C. (1987). Achromobacter xylosoxidans bacteremia. Rev Infect Dis 9, 1001-1005.

Matthews, R. C. \& Preston, N. W. (1997). Bordetella. In Principles and Practice of Clinical Bacteriology, pp. 323-336. Edited by A. M. Emmerson, P. M. Hawkey \& S. H. Gillespie. Chichester: Wiley.

Mesbah, M., Premachandran, U. \& Whitman, W. B. (1989). Precise measurement of the $\mathrm{G}+\mathrm{C}$ content of deoxyribonucleic acid by high-performance liquid chromatography. Int $J$ Syst Bacteriol 39, 159-167.

Middendorf, B. \& Gross, R. (1999). Representational difference analysis identifies a strain-specific LPS biosynthesis locus in Bordetella spp. Mol Gen Genet 262, 189-198.

Moss, C. W. \& Guerrant, G. O. (1983). Separation of bacterial ubiquinones by reverse-phase high-performance liquid chromatography. J Clin Microbiol 18, 15-17.

Müller, M. \& Hildebrandt, A. (1993). Nucleotide sequences of the 23S rRNA genes from Bordetella pertussis, B. parapertussis, B. bronchiseptica and B. avium, and their implications for phylogenetic analysis. Nucleic Acids Res 21, 3320

Musser, J. M., Hewlett, E. L., Peppler, M. S. \& Selander, R. K. (1986). Genetic diversity and relationships in populations of Bordetella spp. J Bacteriol 166, 230-237. 
Petri, R. J. (1887). Eine kleine Modification des Koch'schen Plattenverfahrens. Zentbl Bakteriol Parasitol 1, 279-280.

Pittman, M. (1984). Genus Bordetella Moreno-López 1952, $178^{\mathrm{AL}}$. In Bergey's Manual of Systematic Bacteriology, vol. 1, pp. 388-394. Edited by N. R. Krieg \& J. G. Holt. Baltimore: Williams \& Wilkins.

Porter, J. F., Parton, R. \& Wardlaw, A. C. (1991). Growth and survival of Bordetella bronchiseptica in natural waters and in buffered saline without added nutrients. Appl Environ Microbiol 57, 1202-1206.

Selent, B. (1999). Kombinierter anaerober und aerober Abbau von Chlorbenzolen mit immobilisierten Mikroorganismen. $\mathrm{PhD}$ thesis, Technische Universität Berlin.

Shelton, D. R. \& Tiedje, J. M. (1984). General method for determining anaerobic biodegradation potential. Appl Environ Microbiol 48, 850-857.

Skerman, V. B. D., McGowan, V. \& Sneath, P. H. A. (1980). Approved lists of bacterial names. Int J Syst Bacteriol 30, 225-420.

Stainer, D. W. \& Scholte, M. J. (1970). A simple chemically defined medium for the production of phase I Bordetella pertussis. J Gen Microbiol 63, 211-220.

Stibitz, S. \& Garletts, T. L. (1992). Derivation of a physical map of the chromosome of Bordetella pertussis Tohama I. J Bacteriol 174, 7770-7777.

Tang, Y. W., Hopkins, M. K., Kolbert, C. P., Hartley, P. A., Severance, P. J. \& Persing, D. H. (1998). Bordetella holmesii-like organisms associated with septicemia, endocarditis, and respiratory failure. Clin Infect Dis 26, 389-392.

Temple, L. M., Weiss, A. A., Walker, K. E., Barnes, H. J., Christensen, V. L., Miyamoto, D. M., Shelton, C. B. \& Orndorff, P. E. (1998). Bordetella avium virulence measured in vivo and in vitro. Infect Immun 66, 5244-5251.

Vandamme, P., Hommez, J., Vancanneyt, M., Monsieurs, M., Hoste, B., Cookson, B., Wirsing von König, C. H., Kersters, K. \& Blackall, P. J. (1995). Bordetella hinzii sp. nov., isolated from poultry and humans. Int $J$ Syst Bacteriol 45, 37-45.

Vandamme, P., Heyndrickx, M., Vancanneyt, M., Hoste, B., de Vos, P., Falsen, E., Kersters, K. \& Hinz, K.-H. (1996). Bordetella trematum sp. nov., isolated from wounds and ear infections in humans, and reassessment of Alcaligenes denitrificans Rüger and Tan 1983. Int J Syst Bacteriol 46, 849-858.

Wayne, L. G., Brenner, D. J., Colwell, R. R. \& 9 other authors (1987). International Committee on Systematic Bacteriology. Report of the ad hoc committee on reconciliation of approaches to bacterial systematics. Int J Syst Bacteriol 37, 463-464.

Weisburg, W. G., Barns, S. M., Pelletier, D. A. \& Lane, D. J. (1991).
16S ribosomal DNA amplification for phylogenetic study. $J$ Bacteriol 173, 697-703.

Weiss, A. A. (1992). The genus Bordetella. In The Prokaryotes, 2nd edn, pp. 2530-2543. Edited by A. Balows, H. G. Trüper, M. Dworkin, W. Harder \& K.-H. Schleifer. New York: Springer.

Weyant, R. S., Hollis, D. G., Weaver, R. E. \& 7 other authors (1995). Bordetella holmesii sp. nov., a new Gram-negative species associated with septicemia. J Clin Microbiol 33, 1-7.

von Wintzingerode, F. (1999). Untersuchungen zur mikrobiellen Diversität einer anaeroben, Trichlorbenzol-dechlorierenden Mischkultur. PhD thesis, Humboldt Universität zu Berlin. http://dochost.rz.hu-berlin.de/dissertationen/biologie/wintzingerode-friedrich-von/.

von Wintzingerode, F., Selent, B., Hegemann, W. \& Göbel, U. B. (1999). Phylogenetic analysis of an anaerobic, trichlorobenzenetransforming microbial consortium. Appl Environ Microbiol 65, 283-286.

Woese, C. R., Weisburg, W. G., Paster, B. J., Hahn, C. M., Tanner, R. S., Krieg, N. R., Koops, H.-P., Harms, H. \& Stackebrandt, E. (1984). The phylogeny of purple bacteria: the beta subdivision. Syst Appl Microbiol 5, 327-336.

Woese, C. R., Stackebrandt, E., Macke, T. J. \& Fox, G. E. (1985). A phylogenetic definition of the major eubacterial taxa. Syst Appl Microbiol 6, 143-151.

Woolfrey, F. B. \& Moody, J. A. (1991). Human infections associated with Bordetella bronchiseptica. Clin Microbiol Rev 4, 234-255.

Yabuuchi, E., Kawamura, Y., Kosako, Y. \& Ezaki, T. (1998). Emendation of genus Achromobacter and Achromobacter xylosoxidans (Yabuuchi and Yano) and proposal of Achromobacter ruhlandii (Packer and Vishniac) comb. nov., Achromobacter piechaudii (Kiredjian et al.) comb. nov., and Achromobacter xylosoxidans subsp. denitrificans (Rüger and Tan) comb. nov. Microbiol Immunol 42, 429-438.

Yuk, M. H., Heininger, U., Martinez de Tejada, G. \& Miller, J. F. (1998). Human but not ovine isolates of Bordetella parapertussis are highly clonal as determined by PCR-based RAPD fingerprinting. Infection 26, 270-273.

van der Zee, A., Groenendijk, H., Peeters, M. \& Mooi, F. R. (1996). The differentiation of Bordetella parapertussis and Bordetella bronchiseptica from humans and animals as determined by DNA polymorphism mediated by two different insertion sequence elements suggests their phylogenetic relationship. Int $J$ Syst Bacteriol 46, 640-647.

van der Zee, A., Mooi, F., van Embden, J. \& Musser, J. (1997). Molecular evolution and host adaptation of Bordetella spp.: phylogenetic analysis using multilocus enzyme electrophoresis and typing with three insertion sequences. J Bacteriol 179, 6609-6617. 